http://dx.doi.org/10.4314/ejotmas.v7i1-2.28

\title{
THE PRODUCER-ARTISTIC BUSINESS RELATIONSHIP: A MAJOR CONCERN FOR THE SURVIVAL OF THEATRE PRACTICE IN NIGERIA
}

\author{
*Olatunji Samson SOTIMIRIN, Ph.D.
}

\begin{abstract}
This paper evaluates some of the perennial problems identified by scholars, writers and theatre practitioners as the bane of the growth and survival of theatre practice in Nigeria. These are inadequate funding, non-availability of befitting venues, economic and social insecurity, training and professionalism, orientation of the public sector, technological development, and so on. The central argument, however, is the issue of the business relationship between the producer and the professional theatre artiste. The paper contends that there are many issues concerning the artiste working and struggling to get paid, and artiste being exploited by producers without respectable reward. Consequently, in order to conquer these exploitative tendencies and lack of trust on the part of the producer, the paper submits that it is imperative that the artiste puts his/her professional relationship with the producer on a sound legal footing. This involves not only engaging the use of contracts constricted in agreement with good professional conventions, but also considering the need for the formation of recognized monitoring structures that will be responsible for guiding the actions and behaviour of practitioners. This ought to be done with a governmental support safeguarding the various theatre Associations and guilds as it is the case with other established Associations such as the Institute of Chartered Accountants, Society of Engineers, Nigerian Medical Association and so on. Thus, the method applied to this study is a self-report personality approach where the artistic business of the theatre is evaluated. The paper concludes that although some of the problems highlighted still exist, the situation is gradually improving, especially in terms of the availability of enough befitting venues and regularity of theatre shows at these venues.
\end{abstract}

Keywords: Artistic, Nigeria, Theatre practitioners, Producer-artistic business relationship,

*Olatunji Samson SOTIMIRIN, Ph.D. is of the Department of Creative Arts, Faculty of Arts, University of Lagos, Lagos, Nigeria

Email: tunjisotimirin@yahoo.com 


\section{Introduction}

In Nigeria, there have been a slow pace to theatre progress and many factors have been identified as responsible for the subnormal performance of the industry. The argument tints more on social than a theatre issue, while others related issues ranging from inadequate funding, non-availability of enough befitting venues, economic and social security, training and professionalism, technological development, etc., are also responsible (Sotimirin 220). Peering through this foregrounding, this paper evaluates some of these constraints with a view to determining the level of progress or otherwise, and it also attempts to suggest ways of improving the situation. This is done through extraversion and introversion of artistes in relation to the theatre. The extraversion being the change allowed along the excitement gained through technology while the introversion is the shunning of change and stimulation of change as a sign of faithfulness to tradition. Both are product of the environment and the environment in this case is Nigeria. For the benefits of simplicity and straight forward discussion, the paper is divided into sections. The first section includes problems militating against the growth and survival of theatre practice in Nigeria. Section two examines the main subject of discourse which is the business relationship between the producer and the artiste, while the third and the last section is devoted to conclusion and recommendations. We shall now proceed to examine and highlight the various issues militating against the growth and survival of theatre practice in Nigeria.

\section{Inadequate Funding}

One of the frequent problems connected with theatre practice in Nigeria over the last three decades is ascribed to insufficient funding which in several ways has hindered the dissemination of vital information that could contribute to expanded arts activities and their economic and cultural benefits. Despite the presence of ingenious plays by Wole Soyinka, Femi Osofisan, J.P. Clark, Bode Osanyin, Akinwunmi Ishola, Ben Tomoloju, Tess Onwueme, Zulu Sofola, Ahmed Yerima, OjoRasaki, Segun Adefila, Wole Oguntokun and so many others, with dependable directors and other theatre experts in the country, corporate funding rarely comes to this sector of the entertainment business. In various industrialized places of the world, the theatres are run every day with different presentation and regular audience in attendance (Lambert 23). In Nigeria, theatres are periodic occurrences, with nearly all the locations functioning only on public holidays and festive periods (Dihabua's interview with Sotimirin). Hence, to package a stage play entails the necessary funding which is not an easy task. The theatre 
companies' target is to put on their productions in the best possible ways, and this always involves spending money. Most shows will need to consider the cost of hiring the venue, the technical requirement such as set construction, lights, sound, costumes, make-up, publicity, welfare of cast and crew, transportation, artistes' fees and other production logistics. Opposing to the collective speculation that the condition of theatre is attributable to a regular deterioration in the standard of productions, Sola Adenugba, a graduate of theatre from the University of Ibadan and founder of "Live Theatre on Sunday" argues that "It was not true. The real problem was unlike the 1980 s when theatre enjoyed sponsorship from corporate bodies in the country, nobody was willing to provide funding for plays in Nigeria" (Ohia 56).

For many Nigerian producers and directors who run their own theatre outfits, sponsorships are sometimes secured from personal savings, family and friends in order to keep the faith with the expectations of their business, and most significantly to fulfill the passion which they have for theatre. But the situation is not the same in respect of funding in some other countries where theatre is practised. Oladipo Agboluaje; a Nigerian playwright who is based in London shares his experience on how to improve the quality of Nigerian theatre stating that in terms of theatre, I'll say the UK has a more vibrant industry. Again, a lot of funding for theatre comes from the government. Government money is used to leverage money from the private sector and also to run country developed projects. So, theatre is not just for entertainment, it is also a tool for informing the people and stimulating change. In London, there are many theaters and you can see a different show any day of the week (Adejobi 46).

\section{Economic Instability}

The current economic situation in Nigeria is also a considerable complication to the growth and survival of theatre practice in the country. Nigeria's economy has retrogressed resulting in suffering in the lives of the people. Because of this development, this suffering is further spread to the theatre business, due to the fact that the encouraging theatre sponsorship experienced in the 1970s decreased significantly as a result of the harsh economic situation in Nigeria; together with socio-political insecurity that came about due to the hostile development (Sotimirin 224). Thus, the incursion of funding that frequently supported the accomplishments of theatrical presentation reduced, bringing about a decline in live-theatre productions. As a result of this development, it becomes extremely tough for theatre to flourish. 


\section{Insecurity and Insurgency}

Despite the fact that in the past, lack of sponsorship had lingered, the prevalent upturn and resultant insecurity has heightened the problem. This has made it virtually impossible for theatre to be run sufficiently in performing some of the great plays of practitioners to the general public. Insecurity has led to the decline of audience seeing shows at National Theatre, despite the police post that is right beside the defunct box office. Most audience who see shows here are often afraid of either touts harassing them after evening shows, or the safety of their cars which is often not guaranteed. Not only has this led to the decline in audience attendance, ticket fees for shows in this venue have also been affected. The ticket fee that is usually charged for shows in this theatre is less than what is charged in venues like Muson and Terra Kulture Arena. Audience that once patronized this venue have shifted to other venues like Muson and Terra Kulture Arena, where they feel a sense of security, though there are still some street urchins who disturb audience when they get out of the surroundings (Davies' interview with Tunji Sotimirin).

\section{Dangerous Phase of Technology to Theatre Development}

The prominent and extremely severe "misfortune" of our time is, we are experiencing an era of information which is controlled by technological development and our existence is progressively inhibited by computers and statisticians. This is a good remark but the consequence is that we appear to have misplaced our direction as artistic individuals. The attention on technological development is consequently presumably to make us lose our consciousness of shared creativity. We are losing our consciousness of the purpose of artistic dynamism. It is however important to note that the theatre which is truly and readily a comprehensible art that can impart in us appreciation of moral principles and also permits us to engage artistically in production is of the greatest significance in a theatre creatively driven than technological constructed.

Theatre, an Institution at the core of global civilization now encounters extraordinary threats in a speedily developing culture. From cinematic equivalent YouTube to fashionable phones conflicting with stage and with alternative conventional media for the audiences limited engrossment. An adolescent period nurtured in the middle of an automated sophistication is undoubtedly in stiff contention with a live theatrical enactment. We are such a crazy flux now, according to Lithgow:

The whole notion of entertainment is confused and diffused. It's not just all the 
technologies and the ADD phenomenon of jumping around the video game mind set, we're not sure what entertainment is anymore. Half of television now is reality television, where you have your regular people forcing themselves into limelight and everyday watching happy amateurs failing before their very eyes. Entertainment delivered cheaply to a laptop or handled device beats theatre on price and convenience. These developments threaten live theatre. (Lambert 56)

Having evaluated some of the problems confronting live theatre practice in Nigeria, let us now advance with the investigation of the central argument in this paper which is the producer - artiste business relationship.

\section{Producer-Artiste Relationship in Nigerian Theatre}

A producer is one in charge of overseeing all aspects of financing a production. Though in some productions, the executive producer takes this role in cases where the producer is the one who came up with the idea of the show, but does not have the financial wherewithal. He is also involved in hiring the crew members and has a say in choosing the cast, though the director is largely saddled with this responsibility. Moreover, some producers seem to have had it extremely pleasing, due to their toughness, diligence and most significantly trustworthiness, particularly as they have initiated a respective business relationship with their artistes. To them sincerity is a major consideration. Once they agree to engage an artiste in a project, they always ensure that all the necessary documents are signed by both parties and agreement interpreted and executed in favour of both parties and everybody is happy.

But for some other producers, the contrary is the case. The artiste struggles to get a job and works so diligently without getting appropriately rewarded. Securing a livelihood from a profession is the target of every artiste. This is especially tough in Nigeria for most artistes where years of working for little or no income exist, coupled with producer's exploitation. Jennifer Ossamor; a stage artiste is nontolerant of such producers, as she explains that she does "not waste time to let my fellow colleagues know of such exploiters and their exploits. Some are brave enough to take it up on social media which is vast because presently we don't have a strong union that protects the rights of Artistes that you can go back to." 
Some artistes have been very outspoken on this, saying that they will never work for less than a certain amount, while some others will be glad to quickly grab such a job, even if the money is below the required expectation. Asking for upfront payments has been a strategy employed by most artistes, as Diabuah submits that if these upfront payments are not maid, he will "pull of the project", especially for producers fond of exploiting artiste. Although the court appears to be a place to seek for redress, the excruciating judicial process is a major put off for most artistes, because the money spent seeking for a redress in court, most times exceeds the amount that is going to be paid to artiste. Hence, the reason for loss of faith in the judicial system, as Osammor affirms that suing an artiste is pointless, because she will force the producer "to pay in the end in any which way". Yinka Davies; a prominent actor, and singer is quite optimistic of this issue as she explains that "this is not the time for pointing fingers at who did what or, who stole the casts money, this is the time to set your own team that will be trustworthy, ready to give account, no disrespect, strong and willing to embark on a journey of a lifetime".

The main issue here is that of appropriate remuneration for the artiste. As Ozi Okoli, a member of the National Association of Nigerian Theatre Practitioners who is also a writer, actor, director and TV Producer rightly put it: the major problem has however remained the remuneration of stage actors - stage acts are usually poorly paid. In some cases, a lead actor gets ? 100,000 or less and he is expected to be in rehearsals for weeks, with stipends as rehearsal allowance. But in Nollywood, a single movie role can fetch an actor or actress million, depending on his or her bargaining power, popularity and look (Azuh 34).Explaining further, he adds that stage actors are often considered for entertainment at major events. When they are considered eventually, they get meager remuneration sometimes as low as ! 200,000 for a group while an upcoming musician involved in the same event for instance gets twice the amount (Azuh 46). The issue raised by Ozi Okoli of a lead actor getting 100,000 is changing, as most of these actors now earn from 150,000 to 600,000 for a stage play. Also, the duration of rehearsals is still not commensurate to the money earned, as opposed to filmic actors. A group being paid ; 200,000 has also changed to over ; 500,000 , as stage practitioners are becoming more business conscious unlike the past, where artistes are very passionate to a fault about their crafts. The question again is, how do artistes make reasonable evaluation about whether or not to take an unsatisfactory paid or unpaid job? The position of this paper is clear. It is always the choice of the artiste. His or her decision could be based or the following considerations. 
1. Whether the job is genuinely artistically exciting and if it will develop your technical skills and artiste range.

2. Whether you really want to work with the team, are they intelligent, talented, and respectful of your time?

3. Are they the kind of people you want to hang out with without being paid?

The last decision is of importance here, as artistes are often faced with colleagues or producers who will beg them about doing a free job. This type of free job has been said to bring the supposed "big jobs" by artistes, and often a tool used by some artistes to cajole some them into working with producers. However, the degree of its trueness is very slim, because most of these producers often times go to find other artistes when they get the funds to do other productions. Choosing a play to get involved according to Diabuah is on the following parameters of if the job offers him a chance to improve himself, impact of the job on his carrier, reasonable pay, and if the job is taking him to the next level. Agreeing that the producer has a strong influence in consideration of choosing a job to participate in, Osammor is succinct about her opinions that "welfare is a major factor, working conditions as well and then the fees" if it is worth her while. Even though the pay is of necessity here, consistency is also critical. The problem most artistes often face is that they are more concerned with the fees they are going to be paid, without considering if the producer is consistent with production. Some artistes will rather opt for an inconsistent producer that will pay them 300,000 to 500,000 , neglecting the consistent producer that will pay them : 150,000 to 200,000 per show. This has affected several artistes as they struggle to get another job, after they are done with one.

In the intervening time, how do you make ends meet? This is usually the dilemma of most artistes. Some would engage in a similar, non-artistic vocation which is not a bad idea. But it is important to note that for theatre practice to grow and effectively survive in Nigeria, like in other established traditions of the world, a fee agreement needs to be reached before embarking on a show. This should be in the form of contract. Also, before signing the contract, there are some basic things that the artiste needs to know. Any contract that is endorsed in the path of one's profession as an artiste should require prudent examination and scrutiny by one's lawyer. Contracts undertaken carelessly can fracture one's profession. Aguda clearly explains this thus:

To have a valid contract under Nigerian Law, there must be an offer, acceptance, 
consideration, a consensus addend (which means an agreement of minds) an intention to create legal relationship.

1. What are the terms of the contract?

By the term, I mean, what are the provisions of the agreement, what are the dos and don'ts of both of and the company/producer

2. What is the term of the contract?

The term here means, the duration of the contract.

3. What is the consideration?

The consideration to be paid must be clearly stated. Also, the method of payment, the dates the payment is due (57).

This issue of contract is a thing to be debated especially in Nigerian theatre, where the terms are no longer adhered to, and more so, seeking a redress in court is tedious. Most producers do not even respect contract anymore, to the point that stage artistes are tired of signing contracts because it is really of "no use". In most cases, artistes do not get their copy of the contracts when they eventually get to sign a contract with the producer. In fact, some producers that are in the habit of giving contracts are often times the ones that dupe artistes, because of the knowledge that the legal system is hard and very tough to resolve cases. However, this is not to say artiste should totally neglect contracts, but should be careful enough to read the contract's terms and conditions before appending their signatures. In some cases where an artiste is adamant on singing a contract, the problem of him eventually not getting a job emanates. Due to this, he/she will either be seen as too strong headed or difficult to work. This is always the case with upcoming artiste, as most producers are scared of not adhering to contracts of established artiste.

Therefore, it is important for all artistes to come together and fight this issue, and neglect the standalone attitude that pervades the industry. In the case of contractual agreements, the artiste must agree to the amount of consideration stated and if he/she is not comfortable with the terms, s/he should not sign it. With the understanding of these fundamental objectives and with the assistance of a lawyer, an artiste should be able to enter into a contract knowing whether or not such contract is legally enforceable. We know that sometimes artistes feel demoralized and apathetic about reading and examining their contracts. It can be a lengthy and tedious work. Most of the time, the artiste simply hastily wants to do the work; that's why he/she would waste no time in signing the documents. Regardless of the anxiety with legal documents, contracts are very significant in an artiste's profession. It is desirable accessing some meticulous considerations that can 
translate to a monumental change in practice. On a legal perspective, these are entitlements that any artiste should avoid losing by a surrender or obligation.

\section{The Need for Regulatory Bodies}

Regulatory bodies have proven to be useful in creating terms and conditions to be adhered to, as regards a particular sector. Entertainment industry, with theatre in focus is not left out, as there is currently no functioning regulatory body in the true sense of the word to control the content of plays, and safeguard artistes. It is very essential that theatre practitioners consider the formulation of recognized monitoring structures that will be responsible for guiding the actions and behaviour of artistes with a governmental support safeguarding the various theatre associations and guilds as it is the case with other established associations such as the Institute of Chartered Accountants, Society of Engineers, Institution of Nigerian Estate Surveyors, Nigerian Medical Association and so on. For example, Sotimirin states in his examination of the role of National Associations:

The theatre has not really been accorded due recognition as a profession. It is unlike other professions which have recognized regulatory bodies for their practice. The problem of recognition is very fundamental to professional theatre practice. It is also linked to the issue of remuneration. At the moment, the lack of strong professional Association regulating theatre practice hinders the negotiation of standard remuneration for practitioners. (226)

Although, the National Association of Theatre Arts Practitioners (NANTAP) is existent, this association has not been able to safeguard the rights of the artiste, as most artistes have either pulled out of this association, or uninterested due to the association's non-functionality in terms of looking out for their members. Unlike the Actor's Equity in United States, there is no body in Nigeria, which totally safeguards artistes, and tries to guard against exploitation. Hence, in creating a regulatory body in Nigeria, one of the most important factors that need to be taken into consideration is artiste remuneration. There is currently no base for artiste fee, and hence artistes coming together to fight a case of bad payments is almost impossible, because no association regulates this. Nigerian government therefore needs to step in to make a law that protects the regulatory body and also the right of the artiste.

\section{Conclusion and Recommendations}

The article sought to evaluate some of the perennial problems confronting theatre practice in Nigeria, highlighting critical issues such 
as: inadequate funding, non availability of enough befitting venues, economic and social insecurity, training and professionalism, the orientation of the public sector, technological development and many others. It also comprehensively examined the business relationship between the producer and the artiste, an issue which is considered very fundamental to the poor state of Nigerian theatre practice. The issue of integrity on the part of the producer with regard to how artistes are denied appropriate remuneration is thoroughly discussed with the paper suggesting ways by which the artiste can guard against this sort of treatment. Hence, it recommends that for theatre practice to survive and progress in Nigeria, the following steps should be taken:

\section{Professionalism and Training}

Professionalism amongst theatre practitioners will no doubt assist in continual progress of the practice. Artistes should always endeavour to abide by the ethics and discipline of their profession, as this will help them coordinate themselves and their activities in a progressive manner. They should try to obtain both educational and proficient training to augment their artistry and craftsmanship to face the demand of the present-day audience. Value added artistry will expose them to greater connections and opportunities both locally and internationally.

\section{The Role of Government}

Beyond the responsibility of government which is the absence of determined input in cultural enablement and advancement which has taken an extremely unpleasant proportion, Nigerian rulers need to demonstrate exceeding passion in the matters of theatre business, and they need to acknowledge the importance of the profession as deployment machinery. It is the theatre's capacity to penetrate across communication and ethnic confines. Although despondently, established theatre is striving to restore itself, some people have remained steady with their dedication to stage productions and are constantly working very hard to advance the promotion and progress in their various capacities. Such companies include Kininso Koncepts, Performing Arts Workshop and Studios, Bolanle Austen-Peters Production, Seeing Through the Arts, Crown Troupe of Nigeria, Footprints of David, I-Open Eye Productions, and Declassical Arts and Entertainment, just to mention a few. Of course, there is also the Jos Repertory Theatre founded by Patrick Jude - Oteh in Jos. The Odu Themes Meridien founded by Dr. Bode Sowande in Ibadan. There are other theatre groups spread across the different states and local governments in Nigeria, staging productions at different venues. This is a testimony to the fact that all hope is not lost. In spite of the threat 
of technological advancement, the internet, the video centric incursion and several other challenges, there is still live in the theatre.

\section{Works Cited}

Adejobi, Adedayo. "Competition Will Improve Quality of Nigerian Theatre." ThisDay Newspaper. Lagos: ThisDay Publisher. 2014. Print.

Aguda, Ojonaka. The 5 Basics Every Artist should know before Signing a Public Relations Contract. Web. 12 August 2019 < www.africamusiclaw.com>.

Allport, G. W. Personality: A Psychological Interpretation. New York: Holt. 1937. Print.

Azuh, Maureen. "Theatre Still at the Crossroads." Web. 12 August $2019<w w w . p u n c h n g . c o m / e n t e r t a i n m e n t / a r t s-l i f e / t h e s t r e-s t i l l-$ at-the-crossroads/>.

Davies, Yinka. An Interview with Tunji Sotimirin. 2018.

Diabuah, Patrick. An Interview with Tunji Sotimirin. 2018.

Green, Leda "Theatre's Last Artists Must Adapt to Low Pay during Cuts." The Guardian. Lagos: Guardian Publishers. 2015. Print.

Lambert, Craig (2012). "The Future of Theatre in a Digital Era: Is the Pay Still the Thing?"Harvard Magazine. Web. 12 August 2019 $<$ harvardmagazine.com/2012/01thefutureoftheatre>.

Osammor, Jennifer. An Interview with Tunji Sotimirin. 2018.

Ohai, Chuks "I skip Meals to Fund Theatre." Punch. Ogun: Punch Limited. 2015. Print.

Sotimirin, Tunji "Towards Professional Theatre Practice in Nigeria: The Role of National Associations." Nigerian Journal 8.1 (2005): 217-226. Print. 